\title{
The Role of Contemporary Andrology in Unraveling the Mystery of Unexplained Male Infertility
}

\author{
Alaa Hamada ${ }^{1}$, Sandro C. Esteves ${ }^{2}$ and Ashok Agarwal ${ }^{*}, 1$ \\ ${ }^{I}$ Center for Reproductive Medicine, Cleveland Clinic, Cleveland, USA \\ ${ }^{2}$ ANDROFERT - Andrology and Human Reproduction Clinic, Campinas, Brazil
}

\begin{abstract}
Unexplained male infertility is a condition in which infertile men have normal semen analyses on multiple occasions with no obvious physical or endocrine abnormality when female partner infertility has been ruled out. In addition to erectile problems and coital factors, immune causes and dysfunctional sperm may contribute to such condition. Contemporary andrology may help analyze the unexplained male fertility problem on the basis of cellular and sub-cellular mechanisms and select the proper management. This review highlights the concept of unexplained male infertility and discusses the potential causes and its proper management in the era of modern andrology and assisted reproductive techniques.
\end{abstract}

Keywords: Normospermia, male infertility, immunologic infertility, sperm dysfunction.

\section{INTRODUCTION}

Infertility is defined as the inability of couples to achieve pregnancy after 12 months of unprotected regular intercourse. This condition affects $13-15 \%$ of the couples worldwide [1]. However, the prevalence of such problem differs between countries being higher in the underdeveloped ones [2]. This difference may be attributed to disparity in the resources allocated for diagnosis and treatment. Male factor infertility is responsible for more than $50 \%$ of the problem of the infertility [2]. Male factor is the sole reason in $20 \%$ and has a contributory role in $30-40 \%$ [2].

While impairment in the male reproductive potential can be attributed to various congenital and acquired etiologies such as cryptorchidism, Klinefelter syndrome, vasal atresia, varicocele, genital infection, endocrine disturbance etc. [3], no identifiable cause is found in $37-58 \%$ of cases of male infertility [4-6]. This category is called male infertility of unknown origin that is specifically defined as the impairment in the male reproductive function with spontaneous occurrence or as a result of obscure or unknown cause.

Generally, male infertility of unknown origin is divided into two groups: idiopathic and unexplained varieties. This classification is different from infertility of unknown origin in women as the idiopathic and unexplained point out the same condition. Unexplained male infertility UMI is a subcategory of infertility of unknown origin and accounts for 6$27 \%$ of infertile men [4]. The term UMI is reserved for infertile men with normal semen analyses on two or more occasions with no demonstrable physical or endocrine abnormalities and female factor infertility has been ruled out [7]. On the other hand, idiopathic male infertility is defined

*Address correspondence to this author at the Center for Reproductive Medicine, Cleveland Clinic, Desk A19.1, 9500 Euclid Avenue, Cleveland, Ohio 44195, USA; Tel: (216) 444-9485; E-mail: agarwaa@ccf.org; Website: ccf.org/reproductiveresearchcenter as unexplained reduction in semen quality in terms of sperm count, motility, morphology in males who are normal on physical examination and endocrine testing [5]. This subcategory accounts for $31 \%$ of infertile men [5]. Table 1 clearly shows the prevalence of the two conditions [7].

Table 1. Distribution of Diagnostic Categories in a Male Infertility Clinic [7]

\begin{tabular}{|c|c|}
\hline Category & Frequency \\
\hline Immunological & - \\
\hline Idiopathic & $32.6 \%$ \\
\hline Varicocele & $26.6 \%$ \\
\hline Obstruction & $15.3 \%$ \\
\hline Normal female factor (unexplained male infertility) & $10.7 \%$ \\
\hline Cryptorchidism & $2.7 \%$ \\
\hline Ejaculatory failure & $2.0 \%$ \\
\hline Endocrinologic & $1.5 \%$ \\
\hline Drug/radiation & $1.4 \%$ \\
\hline Genetic & $1.2 \%$ \\
\hline Testicular failure & $1.1 \%$ \\
\hline Sexual dysfunction & $0.7 \%$ \\
\hline Pyospermia & $0.5 \%$ \\
\hline Cancer & $0.4 \%$ \\
\hline Systemic disease & $0.3 \%$ \\
\hline Infection & $0.2 \%$ \\
\hline Torsion & $0.1 \%$ \\
\hline Ultrastructural & $0.1 \%$ \\
\hline Total & $100.0 \%$ \\
\hline
\end{tabular}


The initial assessment of infertile men includes detailed history and physical examination with two proper semen analyses and endocrine testing. This initial evaluation is able to identify the cause of male infertility in roughly half of the patients. However, many others will need to go through the novel and sophisticated andrological tests to discover hidden problems. This article will discuss the potential etiologies and the possible contemporary andrological management outline of the unexplained male infertility problem.

\section{CONCEALED ETIOLOGIES OF UNEXPLAINED MALE INFERTILITY (UMI)}

In general, normal semen analyses do not guarantee fecundity outcomes. The predictive value of normal semen testing in anticipation of natural pregnancy is only $60 \%$ [8]. Table 2 shows the frequency of semen analysis abnormalities in 8,758 infertile patient's attending a fertility clinic [7]. As a matter of fact, it is a seemingly critical situation for both the clinician and the couples with unexplained infertility to find everything is normal on initial lab testing and the couples are childless for a long duration.

Table 2. Distribution of Abnormalities of Semen Parameters in 8758 Patients [8]

\begin{tabular}{|c|c|}
\hline Abnormality in semen parameters & Frequency \\
\hline \hline Azoospermia & $4 \%$ \\
\hline Predominance of a single abnormal parameter & $29 \%$ \\
\hline Motility & $18 \%$ \\
\hline Volume & $2 \%$ \\
\hline Morphology & $7 \%$ \\
\hline Density & $2 \%$ \\
\hline All parameters normal \\
(Unexplained male infertility) & $37 \%$ \\
\hline
\end{tabular}

For men with unexplained infertility the following possibilities should be considered: i) presence of a female factor, ii) inappropriate coital habits, iii) erectile dysfunction, iv) the presence of antisperm antibodies (autoimmune infertility) and iv) sperm dysfunction [7]. To exclude the first three conditions, thorough history taking as well as a complete gynecological evaluation are needed whereas the modern andrology could aid in managing the last two conditions.

\section{Immunologic Infertility}

Immunogenic or autoimmune infertility is defined as an improper bodily immune response, whether humoral or cellular, against sperm antigens that causes sperm dysfunction and renders the male infertile. Generally, it accounts for $4.5 \%$ of the total male fertility problem [5]. However, this percentage may rise up to $40 \%$ among men with UMI [9].

Testis is immunologically privileged site to protect the newly developing haploid spermatozoa from immune recognition. This protection is achieved by the integrity of the blood-testis barrier. Moreover, the integrity of the epithelial barriers augmented by local cellular immunosuppressive barriers account for the isolation of the sperm in the other regions of the male genital tract [10]. Interestingly, there are three postulated theories that explain the origin of loss of immune tolerance to the sperm and mounting of immune reactions against sperm as foreign cells. The first theory hypothesizes that newly developing haploid sperm have different chromosomal make up from somatic cells [11]. The second theory claims that sperm are not present during the embryonic life when immune tolerance occurs to self antigens [12]. Finally, the third theory, known as the immunosuppressive theory, postulates that T-suppressor lymphocytes, which are responsible for inhibition of the immune response against sperm, may be down regulated by continuous leakage of spermatozoal antigens from the genital tract [13]. The two arms of the immune response, humoral and cellular, may be implicated in the etiology of UMI.

\section{Humoral Immune Infertility}

Antisperm antibodies (ASA) are the whole mark of humoral immune infertility. These antibodies are directed to various sperm antigens and implicated in sperm dysfunction. About $10 \%$ of infertile men have ASA versus $2 \%$ of normal fertile men [14]. Nevertheless, Moghissi et al. noticed that the presence of ASA was significantly higher (42.5\%) among patients with unexplained and persistent infertility [9].

The disruption of blood-testis barrier or epithelial barriers, an immunosuppression defect or genital tract insults are the primary mechanisms responsible for leakage of sperm antigens and formation of ASA. However, it is still unknown whether ASA are locally formed within the genital tract or merely transuded from the serum. Specifically speaking, ASA are found in three locations: in the serum, seminal plasma, and sperm-bound. Among these, sperm bound are the most clinically relevant. Moreover, the immunoglobulin (Ig) classes of ASA, namely, IgG which is both locally derived and transuded from serum, and IgA which is thought to be purely locally produced are the most frequently implicated in the pathogenesis of humoral immune infertility [15]. To add further confusion, $7 \%$ to $17 \%$ of infertile women can also produce antisperm antibodies in their cervical fluids $[16,17]$.

ASA interfere with various sperm functions such as induction of apoptosis and acrosome reaction prematurity. ASA may also hinder fertilization event by inhibition of cervical mucus penetration, zona pellucida binding or spermoocyte fusion. Furthermore, ASA may change some macromolecular and sub-cellular function by altering chaperon function, protein folding and disulphide bonds [18]. The end result is that pregnancy rates may be reduced by ASA [19].

Currently, there is sparse evidence, if ever, can be drawn from traditional semen analysis for the presence of ASA. Correspondingly, elevated titers of ASA can be found even in the face of normal semen parameters [20]. Sperm agglutination is the only highly suggestive phenomenon that can be seen in semen analysis in cases of elevated ASA titers [19]. However, this phenomenon is time dependent and 
rarely involves a large proportion of motile spermatozoa soon after liquefaction, even when all ejaculated spermatozoa are antibody coated [19]. In the same manner, the immobilizing and apoptogenic impacts of ASA on the sperm require complement activation which is prevented by the potent anticomplementary substances in the semen [21,22]. Notwithstanding, adequate amount of complement is present in cervical fluid which can be activated through antibody antigen reaction and exert toxic effect on sperm.

The diagnosis of immunological infertility requires two conditions to be satisfied [23]:

a) Fifty percent or more of the motile spermatozoa (progressive and non-progressive) have attached beads. It should be noted, however, that particle binding restricted to the tail tip is not associated with impaired fertility and can be present in fertile men.

b) Sperm-bound antibodies interfere with sperm function; this is usually demonstrated by using functional tests such as the sperm-mucus penetration test, zona binding assays and the acrosome reaction.

Currently, the most popular tests to identify sperm-bound ASA are both the direct immunobead test (IBT) and the direct mixed agglutination reaction (MAR) [24]. In direct IBT, beads coated with covalently-bound rabbit anti-human immunoglobulins against $\operatorname{IgG}$ or $\operatorname{IgA}$ are mixed directly with washed spermatozoa. The binding of beads with anti-human $\operatorname{IgG}$ or IgA to motile spermatozoa indicates the presence of IgG or IgA antibodies on sperm surface [23]. IBT is more time consuming but it identifies the proportion of antibodybound sperm in a given sample, the antibody class and the location of antibodies on sperm surface. On the other hand, direct MAR test is an inexpensive, quick and sensitive screening test where sheep erythrocytes are used instead of immunobeads to detect and localize antibody-bound sperm $[25,26]$. Frequently, antibody-coated sperm may appear as a poor postcoital test [27]. Complement, which is normally found in higher amounts in the cervical mucus than in the seminal plasma, can immobilize antibody-coated spermatozoa. The antibody complement reaction may take at least 6 hours to manifest. Physicians performing a postcoital test (PCT) within $2 \mathrm{~h}$ after intercourse or using in vitro mucus penetration assays may miss the immobilizing antibodies [27]. Consequently, these patients may appear as having an absence of male factor infertility. It is therefore advisable to perform a PCT after at least $6 \mathrm{~h}$ following intercourse [27]. ASA can cause infertility without obvious problems with cervical mucus penetration. Such antibodies may interfere with the acrosome reaction and inhibit sperm penetration into the zona-pellucida and fusion with the oocyte [28].

Not only the exact site and mechanism for ASA production in UMI patients are still unknown but also the implicated sperm antigens are not identified yet. Improvement in recent techniques in sperm surface proteomics may help pinpoint these antigens, improve our understanding of immune infertility and may suggest specific therapy later on.

\section{Cellular Immune Infertility}

Evidence for cellular immune infertility emerges from a variety of human and animal studies on torsion that were able to detect inflammatory cell infiltrate in the contralateral testis in the face of absence of ASA [29,30]. Moreover, cell mediated immunoreactivity has been detected in $50 \%$ of patients with unilateral and $80 \%$ with bilateral surgically repaired cryptorchidism [31]. Meanwhile, sperm exposed to cytokines such as tumor necrosis factor (TNF) and interferon gamma show impairment in motility and inability to penetrate hamster eggs $[32,33]$. Despite these evidences, the full blown spectrum of cellular immune infertility is difficult to demonstrate in the lab and the role of this type of immunogenic infertility in UMI patients is still speculative. Lastly, more sophisticated investigations are needed to detect the impact of cellular immunity in men with unexplained infertility.

\section{Sperm Dysfunction}

In the light of the fact that conventional semen parameters such as sperm count, motility, vitality and morphology are inadequate indicators of sperm function and fertilization potentials [34], contemporary sperm function tests may be of help in delineating these issues. Specifically speaking, sperm function tests may provide more clinically useful prognostic and/or diagnostic information. Such tests may be used to distinguish between fertile and infertile men and to aid in revealing the cause of male subfertility and suggesting therapeutics. Sperm function tests available in the andrology armamentarium include assays that investigate sperm chromosomal and DNA integrity, seminal reactive oxygen species, acrosome reaction, hyperactivated motility and zona pellucida binding and penetration.

\section{Covert Genetic Causes of UMI}

On completion of the meiotic process, germ cells produce 4 haploid spermatids. Meanwhile, Shuffling of some genes occurs between homologous chromosomes during the same process giving rise to genetic diversity. Non-disjunction events during gametogenesis results in either extra or missing chromosome leading to aberrations in the numerical chromosomal complement called "aneuploidy". On the other hand, structural chromosomal complement defects such as deletions, translocations and inversions also occur in sperm or eggs due to chromosomal insults. Both structural and numerical chromosomal complement defects can give rise to dysfunctional sperm. Furthermore, the 4 haploid spermatids undergo the process of spermiogenesis to form mature and motile sperm. Interestingly, during spermiogenesis, the haploid sperm chromatin undergoes significant changes in which most histones are replaced first by transition proteins, then by positively charged protamines [35]. By this remodeling process the sperm DNA condenses so tightly that it is resistant to mechanical stresses such as sonication and even to boiling, which destroy the DNA in somatic cells [36]. The condensation of sperm DNA protects it during its transit through the male and female reproductive tracts. Improper DNA packaging or condensation may result in production of defective sperm. Cytogenetic analysis and molecular biology genetic testing may identify subfertile males misdiagnosed as having unexplained and idiopathic infertility. Covert genetic abnormalities causing male infertility include:

- Alterations in chromosomal complement

- Gene mutation and polymorphisms

- DNA integrity defects 


\section{Alterations in Chromosomal Complement}

The possibility of having sperm chromosomal aneuploidy is inversely related to sperm concentration and total progressive motility [37,38]. Increased sperm aneuploidy rates may impact male fertility and pregnancy viability. The exact causes of aneuploidy are mostly unknown, but smoking, alcohol, chemotherapy and ageing may play a role. The overall frequency of chromosomally abnormal sperm in the general population is estimated to be $7 \%$. Moreover, the mean frequency of disomic sperm (presence of two copies of a chromosome) for autosomes and sex chromosomes are $0.13 \%$ and $0.37 \%$, respectively, while the rate for diploid sperm (two copies of each chromosome) is $0.2 \%[39,40]$. For normospermic infertile males, the corresponding figures are $0.11 \%, 0.44 \%$ and $0.3-1 \%$, respectively $[39,40]$. The actual figures of sperm disomy and diploidy for those men with poor semen quality are even higher.

Interestingly, the inter-chromosomal variation in the rates of disomies has been observed with sex chromosomes and chromosomes 21 and 22; the higher rate of abnormalities related to such chromosomes may be due to their lower rate of meiotic recombination which renders them more prone to non-disjunction [41].

Equally important, both morphologically normal and abnormal spermatozoa can be disomic or diploid [42], or contain damaged DNA [43]; as such, selecting normally looking spermatozoa for ART does not guarantee the absence of chromosomal abnormalities. However, abnormal spermatozoa that retain excess cytoplasm (ERC) exhibit a greater extent of aneuploidy and diploidy than those without ERC from the same ejaculate whether selected by density gradient centrifugation [44], swim-up [45] or binding to hyaluronic acid [46]. Structural chromosomal aberrations such as inversions, deletions, balanced or unbalanced translocations and Y-chromosome microdeletions are often associated with abnormal semen parameters and higher rates of abortion and, in some cases, with higher risk for the birth of a severely handicapped child [47].

Surprisingly, in Y-chromosome microdeletions related infertility, the AZFc region is prone to many smaller subdeletions that are thought to be caused by intrachromosomal recombination [48]. These partial deletions produce a wide array of phenotypes, ranging from normospermia to azoospermia, due to factors that include the interaction of the environment and the genetic background [49].

Most chromosomal abnormalities may be detected by using one of the following methods: (i) Sperm karyotyping for detection of numerical chromosomal abnormalities; (ii) Fluorescence in situ hybridization analysis [50], which can be used to assess numerical and structural chromosomal changes by using specific probes; and (iii) Quantitative Polymerase Chain Reaction (Q-PCR), which is a promising technique to detect and quantify damage to nuclear and mitochondrial DNA [51].

\section{Specific Gene Defect (Mutations and Polymorphisms)}

The sequencing of nucleotide bases in human genome has widely opened the door for recognition of human fertility related genes. Further research has embarked to analyze these genes in the near future. However, DNA sequence analysis is rarely performed in the evaluation of male infertility [52]. In animal studies involving the mice, up to 300 null mutations and 50 conditional targeted deletions have produced models of male infertility. Not only the DNA sequence has an effect on male fertility but there is also a role for epigenetic events and modifiers of gene expression.

It is likely that specific genes play a role in patients with unexplained male infertility since they control meiosis events, spermiogenesis, remodeling, motility, capacitation and fertilization. It is now possible to monitor the expression of thousands of genes simultaneously with DNA microarray analysis. In a comparative analytic study on spermatozoa from normospermic infertile men and fertile healthy controls using microarray technology, hundreds of gene sequences (targets) were differentially expressed between these two groups; there are few genes that are overexpressed whereas all others are underexpressed in infertile men [53].

Novel genetic studies are needed to decipher specific genes that may be implicated in UMI patients. Due to the fact that environmental factors may also influence genetic expression in various ways and may even alter the posttranslational modifications of their products, the imperative dynamic interactions between human genes and environmental factors must be taken in consideration in analyzing gene related fertility problems.

\section{DNA Integrity Defects}

Sperm DNA integrity is increasingly being distinguished as an important marker of fertilizing efficiency, and it is associated with better diagnostic and prognostic values than standard sperm parameters [54]. Saleh et al. reported that an increase of spermatozoa with abnormal chromatin structure or DNA damage (expressed as DNA fragmentation index, DFI) is negatively correlated with intracytoplasmic sperm injection (ICSI) and in vitro fertilization (IVF) outcomes [55].

Significantly, sperm with DNA damage are more often seen in subfertile/infertile men than in fertile ones [56-58]. Successful fertilization of the human ova with spermatozoa with damaged DNA may lead to paternal transmission of defective genetic material with adverse consequences to embryo development $[59,60]$. Approximately $8 \%$ of infertile men have abnormal DNA integrity despite normal semen parameters [61]. The etiologies of such defects are due to variety of extrinsic and intrinsic factors. Heat, smoking, alcohol, radiation and other gonadotoxins are examples of extrinsic factors. The intrinsic factors such as protamine deficiency, mutations that affect DNA packaging, reactive oxygen species and ageing are the main known factors [61].

DNA damage is often assessed by the determination of chromatin compaction or DNA fragmentation. The former examines the accessibility of dyes (acridine blue, aniline blue and chromomycin A3) to nucleoproteins or chromatin after challenging spermatozoa with physical insults; as such, it reflects how susceptible the DNA is, or has been, to noxious agents [62]. Toluidine and aniline blue stains binds to lightly packed chromatin and to lysine residues of acridine that are not fully replaced by protamines, respectively. Chromomycin A3 (CMA3) binding is specific for protamine-deficient areas because of its affinity to guaninecytosine (G-C)-rich areas of DNA [63]. On the other hand, 
DNA fragmentation is measured by detecting single or double strand DNA breaks. TUNEL (Transferase-mediated dTUP nick-end labeling), Comet assay, acridine orange test and SCSA (Sperm Chromatin Structure Assay) are methods clinically available to detect DNA fragmentation. Although they differ in costs and methods, most of the mentioned tests are clinically significant and correlate with sperm function and fertility [64].

\section{Oxidative Stress}

The Imbalance between the production of reactive oxygen species (ROS) and the natural antioxidant defense system is termed as oxidative stress (OS). OS has a pathological effect on sperm function by causing damage to sperm DNA in the nucleus and mitochondria, and inducing lipid peroxidation in the sperm plasma membrane as well as denaturing cellular protein [65]. Mammalian spermatozoa are redox cells that are able to produce reactive oxygen species and to export them to the extracellular medium [6670]. ROS are specifically defined as a group of metabolites formed by reduction of oxygen including free radicals (molecules with unpaired electron) such as superoxide anion $\left(\mathrm{O}_{2}-\bullet\right)$, the hydroxyl radical $(\mathrm{OH} \bullet)$ as well as powerful oxidants such as hydrogen peroxide $\left(\mathrm{H}_{2} \mathrm{O}_{2}\right)$. The origin of ROS in semen is mainly from immature spermatozoa and seminal leukocytes [65].

ROS in low levels have a physiological role. They are required by sperm to attain their functional maturity and are essential for capacitation, hyperactivation and acrosome reaction. ROS also exert their effect on sperm-oocyte interaction. Low levels of lipid peroxidation cause modifications of plasma membranes facilitating sperm adhesion to the oocyte $[71,72]$. However, the true physiological ROS levels are still undetermined.

In fact, sperm are extremely susceptible to the effect of OS because of their high content of polyunsaturated fatty acids (PUFA) in plasma membranes as well as their limited antioxidant defense [73].

ROS are usually associated with poor semen quality and male infertility. It has been shown that $40 \%-88 \%$ of nonselected infertile patients have high levels of seminal ROS [74]. However, recent reports found that normospermic infertile men have higher ROS levels and reduced total antioxidant capacity (TAC) levels than the normospermic fertile counterparts [75]. The exact prevalence of OS in normospermic infertile men is unknown. Nevertheless, a controlled study on limited number of patients detected that $11 \%$ of normospermic infertile men have OS [75].

Interestingly, ROS may seriously impair male reproductive potential without causing gross deteriorations in the semen parameters. This impairment may be explained by deleterious effect of ROS on genetic material and on sperm capacitation and acrosome reaction [76]. In fact, ROS are considered independent markers of male factor infertility [77].

The most often used methods for detecting oxidative stress include methods to measure ROS and methods to measure total antioxidant capacity (TAC). In an andrology setting, ROS measurement techniques are divided into two major categories, i.e., direct methods such as chemilumi- nescence and flow cytometry, and indirect methods such as the colorimetric one. Chemiluminescence uses the probes lucigenin or luminol to detect ROS [78,79]. Luminol $\left(\mathrm{C}_{8} \mathrm{H}_{7} \mathrm{~N}_{3} \mathrm{O}_{2}\right)$ is a versatile chemical that exhibits chemiluminescence with photons emission when mixed with an appropriate oxidizing agent. It can penetrate inside the cell and react with intracellular reactive oxygen species in addition to extracellular ones [79]. Photons produced are converted to an electrical signal and measured by luminometer, with ROS generation being measured as counted photons per minute (cpm) [80]. The normal range is $<0.2 \times 10^{6} \mathrm{cpm}$ per 20 million spermatozoa [81]. Intracellular ROS can be measured by flow cytometry using different fluorescent probes such as 2', 7'-dichlorofluorescin-diacetate, hydroethidine that react with ROS to emit a red fluorescence [82]. The colorimetric technique is also widely used for indirectly quantifying ROS. It is based on the principle of spectrophotometry and measures lipid peroxide end products, mainly malondialdehyde, lipid hydroperoxides and isoprostanes [83].

Various methods for total antioxidant capacity measurements are available such as enhanced chemiluminescence assays, spectrophotometric methods, fluorometric methods such as ORAC assay and electrochemical methods such as coulometry, voltammetry or electron spin resonance assay. Some of these methods are commercially available particularly, spectrophotometric method and fluorometric methods [84].

\section{Impairments in Fertilization Process}

The ability of the sperm to fertilize the ova is related to its potentials of undergoing capacitation, which includes the acquisition of hyperactivated motility, and the acrosomal reaction to penetrate the zona pellucida and its fusigenic ability with oolema. The competent sperm can successfully achieve all these physiological processes culminating in fruitful fertilization outcome. It has been assumed that normospermic infertile men may have defective (incompetent) sperm that are unable to fertilize. This assumption is strengthened by the observation of low success rates of IVF and intrauterine insemination (IUI) in certain cases of unexplained infertility. Various studies examined the defective fertilizing performance of the sperm from different angles encompassing all the stages of sperm-egg interactions.

\section{Zona Pellucida Binding Defects}

Human ZP (hZP) is composed of four major glycoproteins (hZP1, hZP2, hZP3 and hZP4) [85]. Of these, ZP3 of human oocyte is believed to be the primary receptor for capacitated acrosome intact sperm binding $[85,86]$. Typically, sperm binding to ZP is through complimentary, species-specific, receptors or binding sites on the surface of the gametes [87-89]. A number of candidate sperm proteins have been found to be able to interact with either solubilized or intact ZP. However, it is not clear whether or not they are the primary receptors for binding to the ZP [86,90-92]. In fact, sperm binding to ZP3 induces signal transduction pathways within the spermatozoon, involving multiple proteins, particularly protein-kinases $\mathrm{A}$ and $\mathrm{C}$, that lead to the acrosome reaction [93]. Moreover, acrosome-reacted spermatozoa are believed to bind to ZP2 that facilitates the penetra- 
tion to the zona matrix and progression into the perivitelline space [94].

Defective ZP bound sperm are present in approximately $15 \%$ and $25 \%$ of subfertile men with a normal semen analysis and with abnormal ones, respectively [95-97]. Such individuals have a reduced chance of achieving successful fertilization when undergoing IVF [97]. Mackenna et al. reported that two out of 18 men with unexplained infertility showed lack of sperm binding to ZP despite having sperm morphology and hyperactivation status similar to fertile subjects [98]. The presence of defective sperm-zona pellucida binding (DSZPB) in infertile men with normal semen may be due to defective signal transduction pathways upstream of protein kinase A and C. However, most DSZPB infertile men with normal semen and those with severe teratozoospermia are likely to have downstream disorders, structural defects or absence of sperm receptors for binding the $\mathrm{ZP}$.

Two tests of sperm binding to the human zona have been described: i) the hemizona assay and ii) the sperm-zona binding ratio test. In the former, a single zona is bisected and each zona half is incubated with control and patient sperm suspensions [99]. In the latter, a complete zona is incubated with equal numbers of motile spermatozoa from control and test populations, each labeled with a different fluorescent dye [100]. In each case the number of spermatozoa from each population bound per whole or half zona is counted and the number of test sperm expressed as a ratio of that of the control.

\section{Capacitation Defects}

Capacitation is a complex combination of two concomitant processes; mainly, the hyperactivation (HA) in which the sperm acquire a new motility pattern known as hyperactivated motility and the acrosomal reaction (AR) [101]. Defects in capacitation may explain subfertility in some normospermic infertile men.

Hyperactivation (HA) is considered the first step of the complex capacitation process. It involves a typical swimming pattern of movement shown by most sperm retrieved from the oviductal ampulla at the time of fertilization [102]. Hyperactivated sperm exhibit high amplitude and asymmetrical flagellar bending movement. Hyperactivation is characterized by switching of sperm movement from progressive motility to more vigorous (non-progressive) flagellar motion. The role of hyperactivation is to enhance the ability of sperm to detach from the oviduct wall, to move around in its labyrinthine lumen, to penetrate into the cumulus oophorus and, finally, to efficiently drill zona pellucida and reach the oolema [103]. It is speculated that specific signals and physiologic stimuli appear within the oviduct shortly before ovulation and act to induce hyperactivation. These include hormones (e.g. progesterone), ions and secretions in the oviduct luminal fluid [104]. Moreover, when the oocyte enters the oviduct, it usually brings along cumulus oophorus and follicular fluid that have been shown to influence hyperactivation sperm motility as well [105].

Recently, it has been suggested that increased intracellular calcium entry through voltage gated calcium channels (CatSper1-4; Cation channel of Sperm) in the principal piece of the sperm flagellum is the prime mechanism for hyperactivation [106-108]. This entry is induced by intracellular alkalinization due to extrusion of $\mathrm{H}+$ through voltage gated proton pumps which are also located in the principal piece of the flagellum [106]. Increased intracellular $\mathrm{pH}$ and intracellular $\mathrm{Ca}+$ regulate not only the HA process but also the acrosome reaction and the ability of the sperm to fertilize the egg [106]. Molecular studies on CatSper ion channel reveal that it is a novel protein complex that is composed of six subunits. Of these, four are $\alpha$ subunits (CatSper1-4) with calcium selective pore and two are transmembrane proteins with large extracellular domains, called CatSper $\beta$ and CatSper $\gamma$, of unknown functions $[109,110]$.

The extent of hyperactivated motility in a population is positively correlated with the extent of zona binding, the acrosome reaction, zona-free oocyte penetration and fertilizing capacity in vitro [111]. However, only a small proportion of the sperm population may be hyperactivated at each time [105]. Additionally, only the capacitated sperm are able to migrate towards the ovum site, under thermotaxis and chemotaxis stimuli $[112,113]$.

There are specific kinetic concepts that characterize the motility dynamics of HA. These kinetic concepts are measured in vitro by using computerized motion analysis in conjunction to kinematics module to distinguish different subpopulations of motile spermatozoa. HA sperm have high curvilinear velocity (VCL), low linearity (LIN) and large amplitude of the lateral head displacement. The clinical significance of such data is reflected by their correlation with IVF outcomes and spontaneous pregnancy rates [114].

Munire et al. showed that there is a significant decrease in the percentage of hyperactivated sperm, sperm motility, progressive motility, and curvilinear velocity (VCL) from infertile men in comparison to sperm from fertile donors after overnight incubation with capacitating conditions while LIN was increased in the former [115]. Computerized assessment of follicular fluid (FF)-induced hyperactivation (HA) has been proved to be significantly lower in patients with unexplained infertility in comparison with normal fertile men [99]. The absence of HA after the addition of FF was observed in $39 \%$ of patients with unexplained infertility [98], it is likely that spermatozoa from such patients have reduced ability to penetrate through the oocyte vestments and $\mathrm{ZP}$ as a result of this abnormal HA response to FF. Avenarius et al. discovered that male patients with mutated CatSperlgene are infertile with poor HA response despite their normal sperm count, morphology and even their initial motility [116]. Furthermore, an animal study on mice concluded that mutation in each of CatSper ion channel protein can lead to infertility despite of normal semen parameters, normal testicular histology, size and weight [117]. Interestingly, there are two known CatSper2 gene related mutations in humans that cause male infertility, termed CatSper-related nonsyndromic male infertility and deafness-infertility syndrome [118]. However, both syndromes are associated with gross semen abnormalities. Further investigation is needed to disclose the genetic and molecular nature of fertilization in patients with defective HA response and unexplained infertility. Moreover, minor mutations in human CatSper genes are yet to be deciphered in males with unexplained infertility. 


\section{Acrosome Reaction Defects}

The acrosome reaction (AR) is defined as the process of fusion of sperm plasma membrane with outer acrosomal membrane leading to release of exocytotic proteolytic enzymes (acrosine and hyaluronidase) in response to spermzona pellucida binding. Human sperm initiates primary binding to the ZP with intact acrosome [119]. ZP3 is considered the natural stimulus for the AR which leads to the proteolytic dissolution of the zona pellucida [120].

There are two types of defective acrosome reaction which have clinical significance. The first is the acrosome reaction prematurity which is defined as high level of spontaneous acrosome reaction ( $>20 \%$ of spermatozoa exhibiting spontaneous AR) [121]. The second is the AR insufficiency which is defined as poor responsiveness to AR stimulants (when $<15 \%$ of spermatozoa responded to AR stimulants) [121]. Both conditions are associated with poor fertilization capacity on conventional IVF treatment. AR prematurity is usually associated with gross semen abnormalities such as poor sperm motility and abnormal morphology and may be easily diagnosed [122-124].

Some patients with unexplained infertility that have normal sperm-ZP binding have defective ZP-induced AR (AR insufficiency), which will result in reduced sperm-ZP penetration and failure of fertilization [125]. Patients with this condition usually have a long duration of unexplained infertility, normal semen analysis, and normal sperm-ZP binding, but show failure of ZP penetration by sperm and have zero or low rates of fertilization with standard IVF [125]. The diagnostic feature is that very low proportions of sperm undergo AR after binding to the ZP [126]. However, those patients achieve high fertilization and pregnancy rates with ICSI [126]. Although the frequency of defective ZP induced AR (ZPIAR) was high in subfertile men with idiopathic oligozoospermia (65\%) and severe teratozoospermia $(62 \%$, strict normal sperm morphology $\leq 5 \%)$, defective ZPIAR was found in only $25 \%$ of normozoospermic subfertile men [96].

Although the exact mechanisms of AR insufficiency are unknown, defective ZPIAR is more likely to be related to major structural defects of the sperm head, such as small or abnormal acrosome, or associated abnormalities in the overlying plasma membrane in severe teratozoospermic subfertile men. In normozoospermic men, it has been shown that the seminal zinc concentration was significantly higher in men with defective ZPIAR [127]. Zinc is considered one of the decapacitating factors normally present in semen to counteract AR prematurity [128]. Decapacitation factors such as zinc, cholestryl sulphate and other proteins are usually adsorbed on and stabilize the plasma membranes during sperm journey in the male and female reproductive tract until reaching the oviduct [128]. The addition of these decapacitating factors to the culture medium inhibits sperm capacitation and hyperactivated motility, as well as spermatozoa-ZP binding and penetration in vitro [129-132]. Therefore, high seminal zinc concentration may have an adverse effect on the ZPIAR. It is also possible that zinc binding to the sperm plasma membrane affects calcium influx through ion competition during capacitation.
Defective ZPIAR can be caused by different mechanisms in men with or without severe sperm morphological defects. In men with normal sperm morphology, defective ZPIAR is most likely to be due to subtle biochemical or molecular defects in ZP receptors, signal transduction pathways, inefficient cholesterol or zinc removal from the plasma membrane during capacitation, actin polymerization or acrosomal enzyme activation [89,133-138]. Furthermore, it is possible that other prostatic secretions (e.g., citric acid) might affect zinc levels or even sperm function [127]. Zinc levels determination in the seminal plasma is unlikely to be clinically useful for the prediction of defective ZPIAR; currently, only the spermatozoa-ZP interaction tests using human oocyte have been shown to be accurate [127].

To assess the inducibility of AR, artificial stimuli used in vitro to challenge the acrosome reaction such as calcium ionophore A23187 and progesterone. Under normal conditions, $>15 \% \mathrm{AR}$ in response to ionophore treatment is expected [139]. Visualization of acrosome reacted sperm can be achieved using different techniques as follows:

1) Birefringence characteristics of acrosomally reacted spermatozoa under polarized light microscopy [140].

2) Fluorescence microscopy after staining with a fluoresceinated lectins [141,142].

3) Flow cytometry after addition of fluoresceinated antiCD-46 monoclonal antibody [143].

\section{Defective Fusigenic Ability of the Acrosome Reacted Sperm with the Oolema}

The fusigenic potential of the capacitated sperm is represented by ability of the equatorial region of the acrosomereacted human sperm to fuse with the vitelline membrane of the oocyte. The fusigenic ability is usually tested by using the sperm penetration assay (SPA) also known as the zonafree hamster oocyte penetration test. Although this test does not assess sperm-ZP interaction, it measures the spermatozoon's ability to undergo capacitation, acrosome reaction, fusion and penetration through the oolema, and decondensation within the cytoplasm of an oocyte. Basically, the zona pellucida is removed from a hamster oocyte, which is then incubated with human spermatozoa. In the original test scoring is achieved by calculating the percentage of ova which are penetrated; normal sperm are able to penetrate 10$30 \%$ of hamster ova [47]. Recent refinement of this test is performed by incubating sperm in a more potent capacitating media which allow the majority of ova to be penetrated; scores are obtained by calculating the number of sperm that penetrate each ovum [47]. Aitken et al. reported that $34.1 \%$ of patients with unexplained infertility had $<10 \%$ oocyte penetration against $0 \%$ in a control group of fertile men [144]. Various studies have evaluated the ability of the SPA to predict success or failure of IVF. Some investigators have shown no correlation with an abnormal test [145], whereas others have claimed $100 \%$ predictability [146]. Taking an average from different studies, a normal SPA may have $70 \%$ predictability of fertilization in vitro [27]. Nonetheless, semen samples which fail to fertilize hamster ova usually are unable to fertilize human ova [47]. Although the SPA is considered a research tool, it may be of clinical value for men with unexplained infertility with poor fertilization rate on IVF. 
A RATIONAL WORK-UP PLAN FOR THE MANAGEMENT OF MALES WITH UNEXPLAINED INFERTILITY

The initial test for couples with unexplained male infertility is the post-coital test (PCT). PCT is a technically challenging test that must be appropriately timed and performed. Cervical mucus is normally hostile to sperm, except near the time of ovulation. The absence of sperm on a postcoital test in the presence of normal semen parameters suggests incorrect coital technique or failure to ejaculate into vagina while the presence of normal sperm numbers but reduced motility or a shaking motion on a postcoital test is suggestive of the presence of antisperm antibodies [147]. The finding of a normal postcoital test raises the possibility of a functional sperm defect. Assessment of sperm function can be divided into two steps. The first step should be to check the competence of the sperm before fertilization event by measuring the levels of ROS as well as DNA and chromatin integrity defects. The second step should include the assessment of the fertilization potential of sperm especially for those patients with history of prior failure on conventional IVF. These tests include: sperm-ZP binding assay, capacitation, hyperactivation motility, inducibility of acrosome reaction and the ability of sperm to fuse with the vitelline membrane (zona-free hamster egg penetration test) may be used. Fig. (1) depicts the management plan for unexplained male infertility.

\section{TREATMENT STRATEGIES}

The treatment of males with unexplained infertility does not follow the typical rules for standard clinical practice decision making. Such a convention requires specific scientific plan to identify and correct a known defect and calculation of risks versus benefits. Due to the facts that no recognizable reason for infertility is identified and few randomized clinical trials are available, no uniform protocol could be followed. Counseling is an important part of management particularly with regard to orientation about the physiology of ovulation and the need to time intercourse with the periovualtory period. A detailed medical history may help to disclose any hidden problems such as sexual dysfunction and inadequate coitus habits.

\section{Watchful Waiting}

Watchful waiting is advised for young couples with short duration of infertility. Pregnancy may occur spontaneously

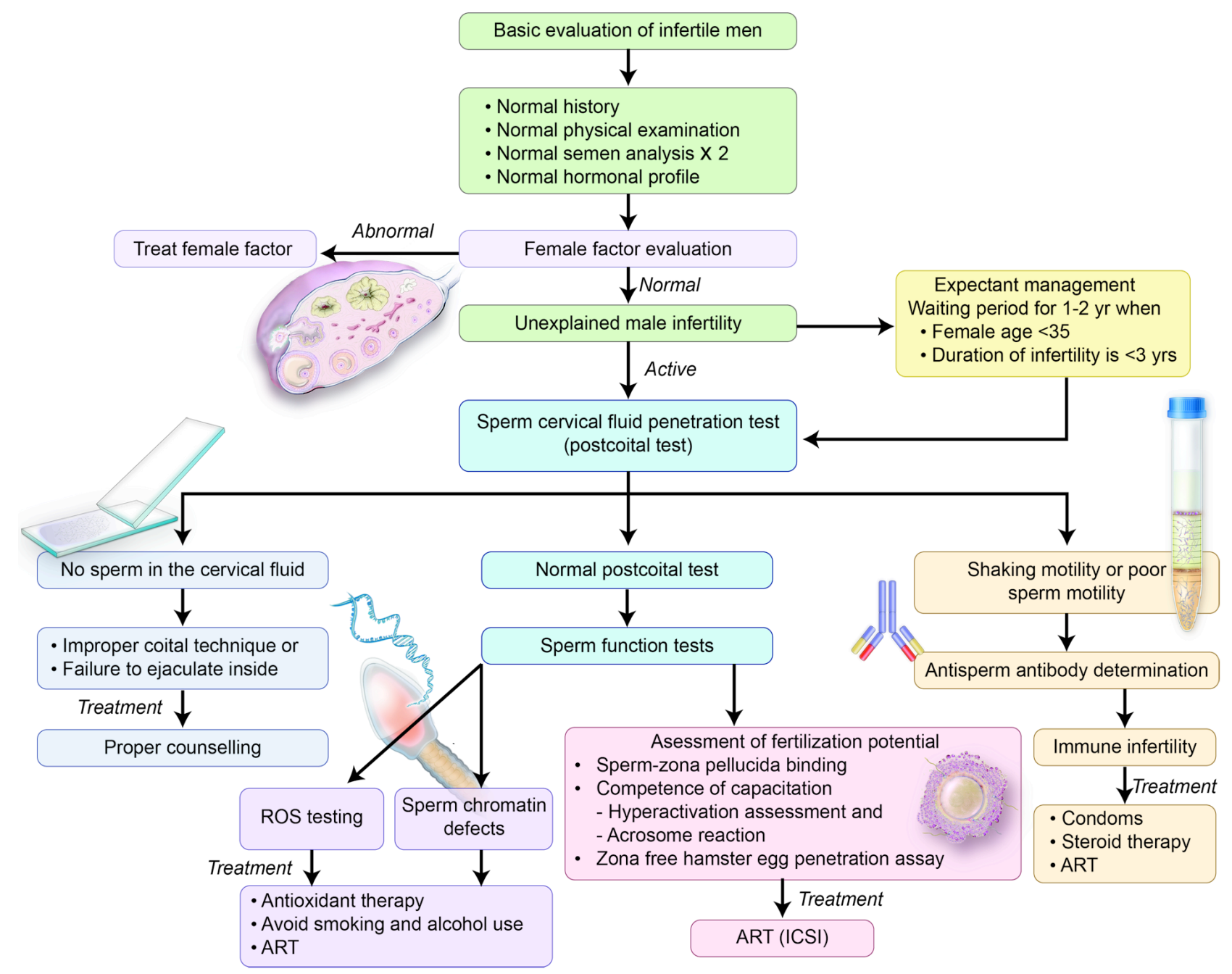

Fig. (1). Work up plan for unexplained male infertility. ROS (reactive oxygen species), ICSI (intracytoplasmic sperm injection), ART (assisted reproductive techniques). 
without any interventions in cases of unexplained infertility [148]. Hull et al. found a cumulative pregnancy rate (PR) ranging from $50-80 \%$ over a 3 -year period as a function of female age and $30-80 \%$ PR as a function of infertility duration [149]. Cumulative pregnancy rates of $60 \%$ may be achieved within 2 years [148]. However, infertility periods longer than 3 years are associated with very low PR of $1-3 \%$ particularly if the female partner is aged 35 years or older [148]. For couples whose time to conceive is longer than three years, the cumulative PR decreases by $2 \%$ for each year of age after 25.7 years [150]. Due to the costs of infertility treatments and given high proportion of couples with unexplained infertility who spontaneously conceive within a 2-year period, it is advisable to defer treatment of couples in this time period unless the female partner is aged 35 years or older.

\section{Interventional Management}

Interventions, which include medication and/or surgery or assisted conception, are justified in cases of unexplained infertility of long duration and/or advanced maternal and paternal age.

\section{Immunological Infertility}

Treatment of immune infertility includes methods to either decrease ASA production or to remove sperm-bound ASA. ASA titers may be decreased by using condoms and systemic steroid. Condoms are of theoretical benefit because they may help to lessen the chances for frequent exposure of sperm to female reproductive tract and hence decrease the sensitization and formation of ASA in cervical mucus [151].

Immunosuppressive therapy had been tried in early years but it is seldom used nowadays mainly because of the high incidence of side-effects [152]. Moreover, efficacy of steroids remains unclear as most studies lack appropriate placebo controls or have used different regimens and drugs. Despite these shortcomings, two prospective and randomized placebo-controlled studies were conducted and showed conflicting results. In the study of Hendry et al, $40 \mathrm{mg}$ of prednisolone was given for a 6-month period from cycle days $1-10$ of the female partner, and then tapered rapidly for the next 2 days [152]. The PR of treated and untreated groups was $31 \%$ and $9 \%$, respectively. In another study, the authors reported similar PR after administration of methylprednisolone for three cycles despite a significant decrease in sperm-associated immunoglobulin $\operatorname{IgG}$ (but not $\operatorname{IgA}$ ) in the steroid treatment group [153]. It has been shown that steroids may be only effective in removing sperm-bound ASA in presence of low antibodies titer [154]. Treatment with high dose steroids for long time is associated with side-effects that include mood changes, fluid retention, dyspepsia, gastrointestinal bleeding, aseptic necrosis of the hip joint, and significant decrease of bone mineral density in up to $60 \%$ of the patients $[152,155,156]$.

Alternatively, methods to remove ASA already bound to sperm include sperm washing and IgA protease treatment. Effectiveness of these techniques in recovering antibodiesfree spermatozoa to be used in assisted reproductive techniques (ARTs) are conflicting; most reports show limited success due to the difficulty of eluting the sperm cell surface by any washing method [157]. Schneider et al. demonstrated that the population of antibodies-free spermatozoa was increased by $29 \%$ after discontinuous colloidal gradient centrifugation. However, the authors observed that sperm washing was ineffective to remove ASA in approximately $30 \%$ of the cases, and advise that the potential benefit of this strategy has to be tested individually [158]. Microinjection of the compromised spermatozoa into the oocyte cytoplasm (ICSI) bypasses sperm-oocyte membrane interaction, and ICSI has been shown to increase fertilization when compared to conventional IVF in cases of male immunologic infertility. Nagy et al. analyzed the outcome of ICSI in men with a proportion of antisperm antibody-bound spermatozoa of $80 \%$ or higher [159]. They concluded that fertilization, cleavage and pregnancy rates after ICSI were not influenced by the percentage of ASA-bound spermatozoa, by the dominant type of antibodies present, or by the location of ASA on the spermatozoa. However, embryo quality was lower in the ASA-positive group [160]. In another study, similar results were observed but a higher rate of first trimester pregnancy loss was observed in the ASA positive group. Clarke et al. and Check et al. studied 39 patients with a strong positivity on IBT $(>80 \%)$ and 93 patients with various degrees of autoantibodies, respectively $[161,162]$. They found that fertilization and pregnancy rates were comparable between different levels of ASA on sperm. Esteves et al. analyzed a large cohort of 351 patients and confirmed that fertilization, cleavage and pregnancy rates after ICSI were not influenced by the ASA levels on sperm [163]. These authors neither observed the negative impact of ASA on embryo quality and cleavage rate nor an increase in pregnancy loss, as reported by others. They also compared ICSI outcomes between patients with ASA positivity and a group of patients in which ICSI was indicated for other reasons. Fertilization, embryo development, pregnancy success and miscarriage rates after ICSI in men exhibiting varying levels of autoimmunity against spermatozoa were within the same range as our population of ICSI patients with severely abnormal seminal parameters. The authors conclude by suggesting that ASA may become inactive within the ooplasm after microinjection, or that a segregation process may take place during the first cleavage divisions, similar to the inactivation and segregation processes that also occur with the acrosome and sperm tail after microinjection.

\section{Excessive Oxidative Stress}

Men with unexplained infertility may have higher oxidative stress than controls $[75,164]$. Lines of therapy include lifestyle habits modification, use of antioxidants and ART. Patients are advised to quit smoking, eat antioxidant-rich food and avoid pollutant environmental conditions. Oral antioxidant therapy has attracted attention in the recent years. Antioxidants are compounds and reactants which dispose, scavenge and suppress the formation of ROS, or oppose their actions. Various antioxidants such as carnitine, vitamin C, vitamin E, coenzyme Q10, selenium, glutathione, N-acetyl cysteine, carotenoids and trace metals are available. A recent Cochrane review on the use of antioxidants for male subfertility suggests that antioxidant supplementation may improve the outcomes of live birth and pregnancy rate for subfertile couples undergoing ART cycles, but further head to head comparisons are necessary to identify the superiority of one antioxidant over another [165]. Additionally, ther- 
apeutic dosing, duration and the toxic levels, if any, of oral antioxidants are still to be determined.

\section{DNA Damage}

The management of unexplained male subfertility due to DNA damage often requires ART. The probability of fertilization in vivo and by intrauterine insemination (IUI) seems to be low when the proportion of sperm cells with DNA damage exceeds $30 \%$ and $12 \%$, as detected respectively by SCSA or TUNEL $[166,167]$. Sperm DNA damage is negatively correlated with embryo quality and blastocyst formation in in vitro fertilization (IVF) cycles and with fertilization rates both in IVF and ICSI cycles [168]. However, successful pregnancies in IVF/ICSI cycles can be obtained using semen samples with a high proportion of DNA damage. Bungum et al. demonstrated that significantly higher clinical pregnancy rates (52.9 \% vs. $22.2 \%)$ and delivery rates $(47.1 \%$ vs. $22.2 \%)$ were obtained after ICSI as compared to IVF when semen samples with high levels of sperm DNA damage were used, as previously suggested [169].

For infertile men with sperm DNA damage with history of multiple failures on IVF/ICSI, it is recommended to use testicular, rather than ejaculated sperm, harvested by either TESE or TESA [170]. Pregnancy rates in first cycles of TESA-ICSI are relatively high in these couples [170] and it has been suggested that if pregnancy does not take place in the first TESA-ICSI cycle, the cause of infertility in these couples may lie elsewhere. Interestingly, it has been hypothesized that the degree of sperm DNA damage increases with time after Sertoli cell release of testicular sperm. Nevertheless, it is controversial to surgically retrieve sperm from men who have sperm in their ejaculates. Other techniques with variable success have been used to select sperm with lower DNA fragmentation index such the use of Annexin-V columns [171,172], and hyaluronic acid binding [46].

Additionally, other sperm selecting techniques based on high resolution imaging of sperm include the selection of spermatozoa devoid of surface vacuoles by high-magnification ICSI [173] and the recently introduced confocal light absorption scattering spectroscopy [174] technology (CLASS). This novel technique allows for the noninvasive visualization of sperm subcellular structures such as intact chromatin to be microinjected by ICSI.

The activation of embryonic genome expression occurs at the four- to eight-cell stage in human embryos. Therefore, the paternal genome may not be effective until that stage and it is speculated that an elevated level of sperm DNA strand breaks seems to be of importance in the later stages of embryonic development. Aitken and Krausz [175] proposed that sperm DNA damage is promutagenic and can give rise to mutations after fertilization, as the oocyte attempts to repair DNA damage prior to the initiation of the first cleavage. Mutations occurring at this point will be fixed in the germline and may be responsible for the induction of infertility, childhood cancer in the offspring and higher risk of imprinting diseases [176]. So far, however, follow-up studies of children born after ICSI compared with children born after conventional IVF have not been conclusive regarding the risks of congenital malformations, imprinting diseases and health problems in general. In vitro fertilization, in general, is associated with multiple gestations and increased risk of congenital abnormalities (including hypospadias) [177]. ICSI in particular, carries an increased risk of endocrine abnormalities, as well as epigenetic imprinting effects [177]. Although the absolute risk of any of these conditions remains low, current data is limited and study populations are heterogenic [177-180]. It is therefore recommended that well-defined groups of couples undergoing ICSI with ejaculated sperm, ICSI with epididymal sperm and ICSI with testicular sperm, and a control group of naturally conceived children are closely followed up.

\section{Fertilization Defects}

ART is indicated for fertilization defects involving sperm capacitation, sperm-ZP interaction or sperm-oocyte fusion. Couples should be advised that significantly higher rate of successful pregnancy achieved with IVF-ICSI compared to conventional IVF and IUI in such cases $[95,126,181]$.

\section{Donor Insemination}

Donor insemination is an alternative when all the above treatment options fail.

\section{EXPERT COMMENTARY}

Remarkable developments have been achieved in the field of andrology in the recent years which significantly improved our understanding of sperm physiology. Novel diagnostic tools envision real time sperm function and may aid in revealing sperm hidden alterations possibly related to infertility. Men facing unexplained infertility are characterized by being childless despite presence of normal semen parameters and normal female partner evaluation. Obviously, classical detailed history taking and physical examination are always necessary to disclose erectile dysfunction problem or irregular coital timing with regard to the periovualtory period. However, when all these measures fail, it is still necessary to go through more sophisticated and expensive tests to monitor sperm function in more detail. ART may solve the problem of unexplained male infertility and bypass all the natural barriers that a dysfunctional sperm must face to achieve fertilization. However, as interventional therapy, ART is not without complications and further studies are needed to refine its role and decrease its impacts on the offspring.

Normal semen parameters do not guarantee fecundity. This concept is important for all clinicians involved in the management of the subfertile male population. Nowadays, one of the main goals of scientists working in the andrology field is to find a diagnostic tool which correlates efficiently with sperm fertilizing potential. The conceptualization of the in vivo process of human fertilization and sperm egg interaction in vitro is the key to disclose sperm functional alterations with tremendous impact on diagnosis and treatment of male infertility.

\section{FIVE-YEAR REVIEW}

The understanding of sperm physiology and fertilization is far from complete. However, molecular and genetic studies are on the pace to give a detailed and thorough 
perception of the entire process of human fertilization. Consequently, this perception may suggest, in the future, specific molecular therapy or even genetic target needed to be precisely modified to improve male reproductive potential.

Moreover, major advances in biomolecular techniques as well as in the sensitivity and accuracy of mass spectrometry are transforming our understanding of sperm physiology. The 'omics' era is under way, which refers to the study of genes (genomics), transcripts (transcriptomics), proteins (proteomics) and the various metabolites (metabolomics). Diagnostic genomics may help us to identify genotypes associated with specific sperm defects, as already reported in animal models [182]. A comprehensive proteomic analysis of normal and defective spermatozoa may provide insights into the structure-function relationships $[183,184]$. It has been suggested that sperm DNA damage is promutagenic and can give rise to mutations after fertilization, as the oocyte attempts to repair DNA damage prior to the initiation of the first cleavage. Mutations occurring at this point will be fixed in the germline and may be responsible for the induction of infertility, childhood cancer in the offspring and higher risk of imprinting diseases [176].

Sperm metabolomics may elucidate which metabolic defects are associated to oxidative stress and sperm damage. This novel information may be useful both to identify the causes or consequences of oxidative stress in the male germline and to tailor individualized therapeutic intervention, such as an optimized regimen of antioxidants. Also in the context of unexplained infertility, glycomic analyses may be useful to reveal the causes of defective sperm-zona interaction [185]. It is then likely that future laboratory semen evaluation will move from the simple assessment of conventional semen profile into the assessment of sperm biochemistry which may aid in the understanding of the underlying physiopathology of male infertility and suggesting options for treatment and prevention.

\section{KEY ISSUES}

- Male infertility of unknown origin is a condition in which fertility impairment occurs spontaneously or due to an obscure or unknown cause. It includes two categories, unexplained male infertility and idiopathic male infertility. The dividing line between them is semen analysis which is normal in unexplained category and abnormal in idiopathic. Unexplained male infertility accounts for $6-27 \%$ of infertile men.

- For men with unexplained infertility and normal semen analyses the following possibilities should be considered: i) presence of a female factor, ii) inappropriate coital habits, iii) erectile dysfunction, iv) the presence of antisperm antibodies (autoimmune infertility) and v) sperm dysfunction. To exclude the first three conditions, thorough history taking as well as a complete gynecological evaluation are needed whereas the modern andrology could aid in managing the last two conditions.

- The initial test for couples with unexplained male infertility is an adequately performed post-coital test (PCT). The absence of sperm on PCT in the presence of normal semen parameters suggests incorrect coital technique or failure to ejaculate into the vagina while the presence of normal sperm numbers but reduced motility or a shaking motion is suggestive of the presence of antisperm antibodies. The finding of a normal postcoital test raises the possibility of a functional sperm defect.

- ASA can cause infertility without obvious problems with cervical mucus penetration. Such antibodies may interfere with the acrosome reaction and inhibit sperm penetration into the zona-pellucida and fusion with the oocyte. The most popular tests to identify sperm-bound ASA are both the direct immunobead test (IBT) and the direct mixed agglutination reaction (MAR).

- Assessment of sperm function can be divided into two steps. The first is to check the competence of the sperm before fertilization by measuring the levels of ROS as well as DNA and chromatin integrity defects. The second is to assess the fertilization potential of sperm. These tests include: sperm-ZP binding assay, capacitation, hyperactivation motility, inducibility of acrosome reaction and the ability of sperm to fuse with the vitelline membrane (zona-free hamster egg penetration test) may be used.

- Watchful waiting is a valid treatment strategy for males with unexplained infertility due to the high spontaneous conception rate particularly when the duration of infertility is $<3$ years and the female partner is aged $\leq 35$ with no detectable functional abnormalities. Active scrutiny for uncommon male fertility problems should commence as soon as possible in couples with diminished chances of spontaneous pregnancy.

- Interventions, which include medication and/or surgery or assisted conception, are justified in cases of unexplained infertility of long duration and/or advanced maternal and paternal age.

- The understanding of sperm physiology and fertilization is far from complete. However, the study of genes (genomics), transcripts (transcriptomics), proteins (proteomics) and the various metabolites (metabolomics) is on the pace to give a detailed and thorough perception of the entire process of human fertilization.

\section{ACKNOWLEDGEMENTS}

None Declared.

\section{CONFLICT OF INTEREST}

None Declared.

\section{REFERENCES}

[1] WHO. Report of the meeting on the prevention of infertility at the primary health care level. Geneva: WHO World Health Organization 1984

[2] Jarow JP, Sharlip ID, Belker AM, et al. Best practice policies for male infertility. J Urol 2002;167(5): 2138-44

[3] Nieschlag E. Classification of andrological disorders. In: Nieschlag E BH, eds Andrology: Male Reproductive Health and Dysfunction. 2nd ed. Berlin2000. 
[4] Moghissi KS, Wallach EE. Unexplained infertility. Fertil Steril 1983;39(1):5-21.

[5] Dohle GR, Diemer T, Giwercman A, Jungwirth A, Kopa Z, Krausz C. Guidelines of male infertility. 2010.

[6] WHO. manual for the standardised investigation and diagnosis of the infertile couple. Cambridge University Press 2000.

[7] Larry I. Lipshultz. Office evaluation of the subfertile male. In: Larry I. Lipshultz SSH, Craig S. Niederberger, editor. Infertility in the Male. 4th ed: Cambridge university press 2009. p. $153-76$.

[8] van der Steeg JW, Steures P, Eijkemans MJ, et al. Role of semen analysis in subfertile couples. Fertil Steril 2010; 95(3):1013-9

[9] Moghissi KS, Sacco AG, Borin K. Immunologic infertility. I. Cervical mucus antibodies and postcoital test. Am J Obstet Gynecol 1980;136(7):941-50.

[10] El-Demiry MI, Hargreave TB, Busuttil A, James K, Ritchie AW, Chisholm GD. Lymphocyte sub-populations in the male genital tract. Br J Urol 1985; 57(6):769-74.

[11] Mahmoud A CF. Immunological causes. In: Comhaire FH HT. Andrology for the clinician. Berlin: Schill W-B Springer 2006; pp. $47-52$.

[12] Billingham RE, Brent L, Medawar PB. Actively acquired tolerance of foreign cells. Nature 1953; 172(4379): 603-6.

[13] Tung K. Autoimmunity of the testis. In: Dhindsa DS SGe.Eds Immunological aspects of infertility and fertility regulation. North Holland, New York: Elsevier 1980; pp. 33-91.

[14] Guzick DS, Overstreet JW, Factor-Litvak P, et al. Sperm morphology, motility, and concentration in fertile and infertile men. N Engl J Med 2001; 345(19):1388-93.

[15] Turek PJ. Male infertility. In: Tanagho E MJ. Smith's General Urology. 17th ed: McGraw-Hill 2008; pp. 684 - 716.

[16] Jones W. The use of antibodies developed by infertile women to identify relevant antigens. Karolinska Symposia on Research Methods in Reproductive Endocrinology Immunological Approach to Fertility Control 1974; Stockholm, Karolinska Institute.

[17] Beer AE, Neaves WB. Antigenic status of semen from the viewpoints of the female and male. Fertil Steril 1978; 29(1): 3-22.

[18] Zsolt Kopa MaBe. Inflammatory parameters of the ejaculate. In: Bjorndahl L GA, Tournaye H, Weidner W. Clinical Andrology EAU/ESAU Course Guidelines: Informa Healthcare 2010; pp. 3018.

[19] Ayvaliotis BR, Rosenfeld D, Cooper G. Conception rates in couples where autoimmunity to sperm is detected. Fertil Steril 1985; 43(5): 739-42.

[20] Francavilla F, Santucci R, Barbonetti A, Francavilla S. Naturallyoccurring antisperm antibodies in men: interference with fertility and clinical implications. An update. Front Biosci 2007; 12: 2890911.

[21] D'Cruz OJ, Haas GG, Jr. Lack of complement activation in the seminal plasma of men with antisperm antibodies associated in vivo on their sperm. Am J Reprod Immunol 1990; 24(2): 51-7.

[22] Petersen BH, Lammel CJ, Stites DP, Brooks GF. Human seminal plasma inhibition of complement. J Lab Clin Med 1980; 96(4): 582-91.

[23] World Health Organization. WHO laboratory manual for the examination and processing of human semen. 5th ed. Geneva: World Health Organization; 2010.

[24] Bronson RA. Antisperm antibodies: a critical evaluation and clinical guidelines. J Reprod Immunol 1999; 45(2): 159-83.

[25] Thomas J WaPJT. Immunological infertility. In: Larry I, Lipshultz SS, Howards and Craig S. Infertility in the male. 4th ed: Cambridge university press 2009; pp. 277-94.

[26] Rajah SV, Parslow JM, Howell RJ, Hendry WF. Comparison of mixed antiglobulin reaction and direct immunobead test for detection of sperm-bound antibodies in subfertile males. Fertil Steril 1992; 57(6): 1300-3.

[27] Check JH, Nowroozi K, Lee M, Adelson H, Katsoff D. Evaluation and treatment of a male factor component to unexplained infertility. Arch Androl 1990; 25(3): 199-211.

[28] Salonen I, Kallajoki M. Monoclonal antibody against human sperm acrosome inhibits sperm penetration of zona-free hamster eggs. Int J Androl 1987; 10(6): 731-9.

[29] Rodriguez MG, Rival C, Theas MS, Lustig L. Immunohistopathology of the contralateral testis of rats undergoing experimental torsion of the spermatic cord. Asian J Androl 2006; 8(5): 576-83.
[30] Anderson MJ, Dunn JK, Lipshultz LI, Coburn M. Semen quality and endocrine parameters after acute testicular torsion. J Urol 1992; 147(6): 1545-50.

[31] Singer R, Dickerman Z, Sagiv M, Laron Z, Livni E. Endocrinological parameters and cell-mediated immunity postoperation for cryptorchidism. Arch Androl 1988 ; 20(2): 153-7.

[32] Perdichizzi A, Nicoletti F, La Vignera S, et al. Effects of tumour necrosis factor-alpha on human sperm motility and apoptosis. $\mathrm{J}$ Clin Immunol 2007; 27(2): 152-62.

[33] Hill JA, Cohen J, Anderson DJ. The effects of lymphokines and monokines on human sperm fertilizing ability in the zona-free hamster egg penetration test. Am J Obstet Gynecol 1989; 160: 1154-9.

[34] Lewis SE. Is sperm evaluation useful in predicting human fertility? Reproduction 2007; 134(1): 31-40.

[35] Meistrich ML, Mohapatra B, Shirley CR, Zhao M. Roles of transition nuclear proteins in spermiogenesis. Chromosoma 2003; 111(8): 483-8.

[36] Tateno H, Kimura Y, Yanagimachi R. Sonication per se is not as deleterious to sperm chromosomes as previously inferred. Biol Reprod 2000; 63(1): 341-6.

[37] Vegetti W, Van Assche E, Frias A, et al. Correlation between semen parameters and sperm aneuploidy rates investigated by fluorescence in-situ hybridization in infertile men. Hum Reprod 2000; 15(2): 351-65.

[38] Collodel G, Capitani S, Baccetti B, Pammolli A, Moretti E. Sperm aneuploidies and low progressive motility. Hum Reprod 2007; 22(7): 1893-8.

[39] Egozcue S, Blanco J, Vendrell JM, et al. Human male infertility: chromosome anomalies, meiotic disorders, abnormal spermatozoa and recurrent abortion. Hum Reprod Update 2000; 6(1): 93-105.

[40] Rives N, Saint Clair A, Mazurier S, et al. Relationship between clinical phenotype, semen parameters and aneuploidy frequency in sperm nuclei of 50 infertile males. Hum Genet 1999; 105(3): 26672.

[41] Thomas NS, Hassold TJ. Aberrant recombination and the origin of Klinefelter syndrome. Hum Reprod Update 2003; 9(4): 309-17.

[42] Celik-Ozenci C, Catalanotti J, Jakab A, et al. Human sperm maintain their shape following decondensation and denaturation for fluorescent in situ hybridization: shape analysis and objective morphometry. Biol Reprod 2003; 69(4): 1347-55.

[43] Avendano C, Franchi A, Taylor S, Morshedi M, Bocca S, Oehninger S. Fragmentation of DNA in morphologically normal human spermatozoa. Fertil Steril 2009; 91(4): 1077-84.

[44] Kovanci E, Kovacs T, Moretti E, et al. FISH assessment of aneuploidy frequencies in mature and immature human spermatozoa classified by the absence or presence of cytoplasmic retention. Hum Reprod 2001; 16(6): 1209-17.

[45] Jakab A, Kovacs T, Zavaczki Z, et al. Efficacy of the swim-up method in eliminating sperm with diminished maturity and aneuploidy. Hum Reprod 2003; 18(7): 1481-8.

[46] Jakab A, Sakkas D, Delpiano E, et al. Intracytoplasmic sperm injection: a novel selection method for sperm with normal frequency of chromosomal aneuploidies. Fertil Steril 2005; 84(6): 1665-73.

[47] Zini A SM. Evaluation of Sperm Function. In: Larry I, Lipshultz SS, Howards and Craig S. Infertility in the male. Cambrige university press 2009; pp. 177- 98.

[48] Ferlin A, Raicu F, Gatta V, Zuccarello D, Palka G, Foresta C. Male infertility: role of genetic background. Reprod Biomed Online 2007; 14(6): 734-45.

[49] O'Flynn O'Brien KL, Varghese AC, Agarwal A. The genetic causes of male factor infertility: a review. Fertil Steril 2010; 93(1): 1-12.

[50] Aitken RJ, Clarkson JS, Fishel S. Generation of reactive oxygen species, lipid peroxidation, and human sperm function. Biol Reprod 1989; 41(1): 183-97.

[51] Wieacker MSaP. Cytogenetic and Molecular Genetic Investigations. In: Eberhard Nieschlag HMB, Susan Nieschlag, Eds. Andrology Male Reproductive Health and Dysfunction: Springer-Verlag Berlin Heidelberg 2010; pp. 119-26.

[52] Dolores JA. look towards the future advances in andrology expected to revolutionize the diagnosis and treatment of infertile men. In: Larry I. Lipshultz SS, Howards and Craig S, Eds. Infertilty in the male: Cambridge university press 2009; pp. 642-53.

[53] Garrido N, Martinez-Conejero JA, Jauregui J, et al. Microarray analysis in sperm from fertile and infertile men without basic sperm 
analysis abnormalities reveals a significantly different transcriptome. Fertil Steril 2009; 91(Suppl 4): 1307-10.

[54] Agarwal A, Allamaneni SS. The effect of sperm DNA damage on assisted reproduction outcomes: A review. Minerva Ginecol 2004; 56(3): 235-45.

[55] Saleh RA, Agarwal A, Nada EA, et al. Negative effects of increased sperm DNA damage in relation to seminal oxidative stress in men with idiopathic and male factor infertility. Fertil Steril 2003; 79 (Suppl 3): 1597-605.

[56] Evenson DP, Darzynkiewicz Z, Melamed MR. Relation of mammalian sperm chromatin heterogeneity to fertility. Science 1980; 210(4474): 1131-3.

[57] Henkel R, Hajimohammad $\mathrm{M}$, Stalf $\mathrm{T}$, et al. Influence of deoxyribonucleic acid damage on fertilization and pregnancy. Fertil Steril 2004; 81(4): 965-72.

[58] Tesarik J, Greco E, Mendoza C. Late, but not early, paternal effect on human embryo development is related to sperm DNA fragmentation. Hum Reprod 2004; 19(3): 611-5.

[59] Aitken RJ, Baker MA, Sawyer D. Oxidative stress in the male germ line and its role in the aetiology of male infertility and genetic disease. Reprod Biomed Online 2003; 7(1): 65-70.

[60] Bakos HW, Thompson JG, Feil D, Lane M. Sperm DNA damage is associated with assisted reproductive technology pregnancy. Int $\mathrm{J}$ Androl 2008; 31(5): 518-26.

[61] The clinical utility of sperm DNA integrity testing. Fertil Steril 2006; 86(5Suppl 1): 35-7.

[62] Yeung C CT. Sperm Quality and Function Tests. Andrology, Male Reproductive Health and Dysfunction: Springer-Verlag Berlin Heidelberg 2010; pp. 139-54.

[63] Manicardi GC, Tombacco A, Bizzaro D, Bianchi U, Bianchi PG, Sakkas D. DNA strand breaks in ejaculated human spermatozoa: comparison of susceptibility to the nick translation and terminal transferase assays. Histochem J 1998; 30(1): 33-9.

[64] Henkel R, Maass G, Hajimohammad M, et al. Urogenital inflammation: changes of leucocytes and ROS. Andrologia 2003; 35(5): 309-13.

[65] Bennetts RJ. The Sperm Cell Production, Maturation, Fertilization, Regeneration. In: Christopher J. De Jonge CLRB, Eds. Reactive oxygen species: friend or foe. Cambridge University Press 2006; pp. 170-93.

[66] Alvarez JG, Storey BT. Spontaneous lipid peroxidation in rabbit and mouse epididymal spermatozoa: dependence of rate on temperature and oxygen concentration. Biol Reprod 1985; 32(2): $342-51$.

[67] Holland MK, Alvarez JG, Storey BT. Production of superoxide and activity of superoxide dismutase in rabbit epididymal spermatozoa. Biol Reprod 1982; 27(5): 1109-18.

[68] Alvarez JG, Touchstone JC, Blasco L, Storey BT. Spontaneous lipid peroxidation and production of hydrogen peroxide and superoxide in human spermatozoa. Superoxide dismutase as major enzyme protectant against oxygen toxicity. J Androl 1987; 8(5): $338-48$.

[69] Alvarez JG, Storey BT. Lipid peroxidation and the reactions of superoxide and hydrogen peroxide in mouse spermatozoa. Biol Reprod 1984; 30(4): 833-41.

[70] Aitken RJ, Clarkson JS. Cellular basis of defective sperm function and its association with the genesis of reactive oxygen species by human spermatozoa. J Reprod Fertil 1987; 81(2): 459-69.

[71] Griveau JF, Le Lannou D. Reactive oxygen species and human spermatozoa: physiology and pathology. Int J Androl 1997; 20(2): 61-9.

[72] Agarwal A, Nallella KP, Allamaneni SS, Said TM. Role of antioxidants in treatment of male infertility: an overview of the literature. Reprod Biomed Online 2004; 8(6): 616-27.

[73] Henkel RR. Leukocytes and oxidative stress: dilemma for sperm function and male fertility. Asian J Androl 2011; 13(1): 43-52.

[74] Lewis SE, Boyle PM, McKinney KA, Young IS, Thompson W. Total antioxidant capacity of seminal plasma is different in fertile and infertile men. Fertil Steril 1995; 64(4): 868-70.

[75] Pasqualotto FF, Sharma RK, Kobayashi H, Nelson DR, Thomas AJ $\mathrm{Jr}$, Agarwal A. Oxidative stress in normospermic men undergoing infertility evaluation. J Androl. 2001; 22(2): 316-22.

[76] Bansal AK, Bilaspuri GS. Impacts of Oxidative Stress and Antioxidants on Semen Functions 2010
[77] Agarwal A, Sharma RK, Nallella KP, Thomas AJ Jr., Alvarez JG, Sikka SC. Reactive oxygen species as an independent marker of male factor infertility. Fertil Steril 2006; 86(4): 878-85.

[78] Aitken RJ, Buckingham DW, West KM. Reactive oxygen species and human spermatozoa: analysis of the cellular mechanisms involved in luminol- and lucigenin-dependent chemiluminescence. J Cell Physiol 1992; 151(3): 466-77.

[79] Aitken RJ, Baker MA, O'Bryan M. Shedding light on chemiluminescence: the application of chemiluminescence in diagnostic andrology. J Androl 2004; 25(4): 455-65.

[80] Fraga CG, Motchnik PA, Shigenaga MK, Helbock HJ, Jacob RA, Ames BN. Ascorbic acid protects against endogenous oxidative DNA damage in human sperm. Proc Natl Acad Sci USA 1991; 88(24): 11003-6.

[81] Agarwal A, Abdelrazik H, Sharma RK. Oxidative stress measurement in patients with male or female factor infertility. Handbook of Chemiluminescent Methods in Oxidative Stress Assessment 2008; pp 195-218.

[82] Marchetti C, Obert G, Deffosez A, Formstecher P, Marchetti P. Study of mitochondrial membrane potential, reactive oxygen species, DNA fragmentation and cell viability by flow cytometry in human sperm. Hum Reprod 2002; 17(5): 1257-65.

[83] Agarwal A, Makker K, Sharma R. Clinical relevance of oxidative stress in patients with male factor infertility: evidence-based analysis. An update Am J Reprod Immunol 2008; 59(1): 2-11.

[84] Fingerova H, Novotny J, Barborik J, et al. Antioxidant capacity of seminal plasma measured by TAS Randox. Biomed Pap Med Fac Univ Palacky Olomouc Czech Repub 2007; 151(1): 37-40.

[85] Lefievre L, Conner SJ, Salpekar A, et al. Four zona pellucida glycoproteins are expressed in the human. Hum Reprod 2004; 19(7): 1580-6.

[86] Bleil JD, Wassarman PM. Identification of a ZP3-binding protein on acrosome-intact mouse sperm by photoaffinity crosslinking. Proc Natl Acad Sci USA 1990; 87(14): 5563-7.

[87] Ahuja KK. Carbohydrate determinants involved in mammalian fertilization. Am J Anat 1985; 174(3): 207-23.

[88] Oehninger S. Molecular basis of human sperm-zona pellucida interaction. Cells Tissues Organs 2001; 168(1-2): 58-64.

[89] Yanagimachi R. Mammalian fertilization. In: Neill NK, Eds The Physiology of Reproduction: New York: Raven Press 1994; pp. 189- 317.

[90] Wassarman PM. Mammalian fertilization: molecular aspects of gamete adhesion, exocytosis, and fusion. Cell 1999; 96(2): 175-83.

[91] Lasserre A, Gonzalez-Echeverria F, Moules C, Tezon JG, Miranda $\mathrm{PV}$, Vazquez-Levin MH. Identification of human sperm proteins involved in the interaction with homologous zona pellucida. Fertil Steril 2003; 79 (Suppl 3): 1606-15.

[92] van Gestel RA, Brewis IA, Ashton PR, Brouwers JF, Gadella BM. Multiple proteins present in purified porcine sperm apical plasma membranes interact with the zona pellucida of the oocyte. Mol Hum Reprod 2007; 13(7): 445-54

[93] Thaler CD, Cardullo RA. The initial molecular interaction between mouse sperm and the zona pellucida is a complex binding event. $\mathrm{J}$ Biol Chem 1996; 271(38): 23289-97.

[94] Consensus workshop on advanced diagnostic andrology techniques. ESHRE (European Society of Human Reproduction and Embryology) Andrology Special Interest Group. Hum Reprod 1996; 11(7): 1463-79.

[95] Liu DY, Garrett C, Baker HW. Clinical application of spermoocyte interaction tests in in vitro fertilization--embryo transfer and intracytoplasmic sperm injection programs. Fertil Steril 2004; 82(5): 1251-63.

[96] Liu de Y, Liu ML, Garrett C, Baker HW. Comparison of the frequency of defective sperm-zona pellucida (ZP) binding and the ZP-induced acrosome reaction between subfertile men with normal and abnormal semen. Hum Reprod 2007; 22(7): 1878-84.

[97] Liu DY, Clarke GN, Lopata A, Johnston WI, Baker HW. A spermzona pellucida binding test and in vitro fertilization. Fertil Steril 1989; 52(2): 281-7

[98] Mackenna A, Barratt CL, Kessopoulou E, Cooke I. The contribution of a hidden male factor to unexplained infertility. Fertil Steril 1993; 59(2): 405-11.

[99] Burkman LJ, Coddington CC, Franken DR, Krugen TF, Rosenwaks Z, Hogen GD. The hemizona assay (HZA): development of a diagnostic test for the binding of human spermatozoa to the human 
hemizona pellucida to predict fertilization potential. Fertil Steril 1988; 49(4): 688-97.

[100] Liu DY, Lopata A, Johnston WI, Baker HW. A human sperm-zona pellucida binding test using oocytes that failed to fertilize in vitro. Fertil Steril 1988; 50(5): 782-8.

[101] Esteves SC, Sharma RK, Thomas AJ Jr, Agarwal A. Effect of in vitro incubation on spontaneous acrosome reaction in fresh and cryopreserved human spermatozoa. Int J Fertil Womens Med 1998; 43(5): 235-42.

[102] Esteves SC, Sharma RK, Thomas AJ Jr, Agarwal A. Effect of swim-up sperm washing and subsequent capacitation on acrosome status and functional membrane integrity of normal sperm. Int $\mathbf{J}$ Fertil Womens Med 2000; 45(5): 335-41.

[103] Suarez SS, Ho HC. Hyperactivated motility in sperm. Reprod Domest Anim 2003; 38(2): 119-24.

[104] Nichol R, Hunter RH, Gardner DK, Leese HJ, Cooke GM. Concentrations of energy substrates in oviductal fluid and blood plasma of pigs during the peri-ovulatory period. J Reprod Fertil 1992; 96(2): 699-707.

[105] Mortimer ST, Swan MA. Variable kinematics of capacitating human spermatozoa. Hum Reprod 1995; 10(12): 3178-82.

[106] Lishko PV, Kirichok Y. The role of Hv1 and CatSper channels in sperm activation. J Physiol; 588: 4667-72.

[107] Suarez SS. Control of hyperactivation in sperm. Hum Reprod Update 2008;14(6): 647-57.

[108] Carlson AE, del Camino D, Quill TA, et al. Pharmacological targeting of native CatSper channels reveals a required role in maintenance of sperm hyperactivation. PLoS One [serial on the Internet]. 2009; 4(8).

[109] Liu J, Xia J, Cho KH, Clapham DE, Ren D. CatSperbeta, a novel transmembrane protein in the CatSper channel complex. J Biol Chem 2007; 282(26): 18945-52.

[110] Wang H, Liu J, Cho KH, Ren D. A novel, single, transmembrane protein CATSPERG is associated with CATSPER1 channel protein. Biol Reprod 2009; 81(3): 539-44.

[111] Cooper TG. Physiology of Sperm Maturation and Fertilization. In: Nieschlag E BH, editor. Andrology: Male Reproductive Health and Dysfunction. 3rd ed: Springer-Verlag Berlin Heidelberg 2010; pp 61-86.

[112] Bahat A, Eisenbach M. Sperm thermotaxis. Mol Cell Endocrinol 2006; 252(1-2): 115-9.

[113] Eisenbach M, Giojalas LC. Sperm guidance in mammals - an unpaved road to the egg. Nat Rev Mol Cell Biol 2006; 7(4): 27685.

[114] Garrett C, Liu DY, Clarke GN, Rushford DD, Baker HW. Automated semen analysis: 'zona pellucida preferred' sperm morphometry and straight-line velocity are related to pregnancy rate in subfertile couples. Hum Reprod 200; 18(8): 1643-9.

[115] Munire M, Shimizu Y, Sakata Y, Minaguchi R, Aso T. Impaired hyperactivation of human sperm in patients with infertility. J Med Dent Sci 2004; 51(1): 99-104.

[116] Avenarius MR, Hildebrand MS, Zhang Y, et al. Human male infertility caused by mutations in the CATSPER1 channel protein. Am J Hum Genet 2009; 84(4): 505-10.

[117] Qi H, Moran MM, Navarro B, et al. All four CatSper ion channel proteins are required for male fertility and sperm cell hyperactivated motility. Proc Natl Acad Sci USA 2007; 104(4): 1219-23.

[118] Hildebrand MS, Avenarius MR, Smith RJH. CATSPER-Related Male Infertility. In: Pagon RA, Bird TD, Dolan CR, Stephens K, Eds. Source GeneReviews [Internet]. Seattle (WA): University of Washington, Seattle; 1993-2009 Dec 03. Available online from: http://0-www.ncbi.nlm.nih.gov.library.ccf.org/pubmed/20301780.

[119] Liu DY, Baker HW. Inducing the human acrosome reaction with a calcium ionophore A23187 decreases sperm-zona pellucida binding with oocytes that failed to fertilize in vitro. J Reprod Fertil 1990; 89(1): 127-34.

[120] Cross NL, Morales P, Overstreet JW, Hanson FW. Induction of acrosome reactions by the human zona pellucida. Biol Reprod 1988; 38(1): 235-44.

[121] Sigman M, Baazeem A, Zini A. Semen analysis and sperm function assays: what do they mean? Semin Reprod Med 2009; 27(2): 11523.

[122] Parinaud J, Vieitez G, Moutaffian H, Richoilley G, Labal B. Variations in spontaneous and induced acrosome reaction: correlations with semen parameters and in-vitro fertilization results. Hum Reprod 1995; 10(8): 2085-9.

[123] Carrell DT, Zobell RL, Middleton RG, Urry RL. A functional analysis and the potential clinical significance of 7 categories of sperm morphology. J Urol 1994; 151(2): 376-80.

[124] Heywinkel E, Freundl G, Hofmann N. Acrosome reaction of spermatozoa with different morphology. Andrologia 1993; 25(3): 137-9.

[125] Liu DY, Baker HW. Disordered acrosome reaction of spermatozoa bound to the zona pellucida: a newly discovered sperm defect causing infertility with reduced sperm-zona pellucida penetration and reduced fertilization in vitro. Hum Reprod 1994; 9(9): 1694700.

[126] Liu DY, Bourne H, Baker HW. High fertilization and pregnancy rates after intracytoplasmic sperm injection in patients with disordered zona pellucida-induced acrosome reaction. Fertil Steril 1997; 67(5): 955-8.

[127] Liu DY, Sie BS, Liu ML, Agresta F, Baker HW. Relationship between seminal plasma zinc concentration and spermatozoa-zona pellucida binding and the ZP-induced acrosome reaction in subfertile men. Asian J Androl 2009; 11(4): 499-507.

[128] de Lamirande E, Leclerc P, Gagnon C. Capacitation as a regulatory event that primes spermatozoa for the acrosome reaction and fertilization. Mol Hum Reprod 1997; 3(3): 175-94.

[129] Kanwar KC, Yanagimachi R, Lopata A. Effects of human seminal plasma on fertilizing capacity of human spermatozoa. Fertil Steril 1979; 31(3): 321-7.

[130] Cross NL. Multiple effects of seminal plasma on the acrosome reaction of human sperm. Mol Reprod Dev 1993; 35(3): 316-23.

[131] Levay PF, Fourie FR, Meintjes J. The effect of seminal plasma on human sperm-zona pellucida binding. Hum Reprod 1995; 10(10): 2590-4.

[132] Mortimer ST, Swan MA, Mortimer D. Effect of seminal plasma on capacitation and hyperactivation in human spermatozoa. Hum Reprod 1998; 13(8): 2139-46.

[133] Lee MA, Kopf GS, Storey BT. Effects of phorbol esters and a diacylglycerol on the mouse sperm acrosome reaction induced by the zona pellucida. Biol Reprod 1987; 36(3): 617-27.

[134] Tollner TL, Overstreet JW, VandeVoort CA. Effect of protein kinase $\mathrm{C}$ stimulators on zona pellucida binding and the acrosome reaction of macaque sperm. Biol Reprod 1995; 52(6): 1418-25.

[135] Cross NL. Human seminal plasma prevents sperm from becoming acrosomally responsive to the agonist, progesterone: cholesterol is the major inhibitor. Biol Reprod 1996; 54(1): 138-45.

[136] Liu DY, Baker HW. Protein kinase C plays an important role in the human zona pellucida-induced acrosome reaction. Mol Hum Reprod 1997; 3(12): 1037-43.

[137] Liu DY, Martic M, Clarke GN, et al. An anti-actin monoclonal antibody inhibits the zona pellucida-induced acrosome reaction and hyperactivated motility of human sperm. Mol Hum Reprod 2002; 8(1): 37-47.

[138] Cohen G, Rubinstein S, Gur Y, Breitbart H. Crosstalk between protein kinase $\mathrm{A}$ and $\mathrm{C}$ regulates phospholipase $\mathrm{D}$ and F-actin formation during sperm capacitation. Dev Biol 2004; 267(1): 23041.

[139] Esteves SC, Sharma RK, Thomas AJ, Jr., Agarwal A. Cryopreservation of human spermatozoa with pentoxifylline improves the post-thaw agonist-induced acrosome reaction rate. Hum Reprod 1998; 13(12): 3384-9.

[140] Gianaroli L, Magli MC, Ferraretti AP, et al. Birefringence characteristics in sperm heads allow for the selection of reacted spermatozoa for intracytoplasmic sperm injection. Fertil Steril 2008; 93(3): 807-13.

[141] Esteves SC, Sharma RK, Thomas AJ Jr, Agarwal A. Evaluation of acrosomal status and sperm viability in fresh and cryopreserved specimens by the use of fluorescent peanut agglutinin lectin in conjunction with hypo-osmotic swelling test. Int Braz J Urol 2007; 33(3): 364-74.

[142] Cross NL MP OJ, Hanson FW. Two simple methods for detecting acrosome reacted human sperm. Gamete Res 1986; 15(3): 213-26.

[143] Miyazaki R, Fukuda M, Takeuchi H, Itoh S, Takada M. Flow cytometry to evaluate acrosome-reacted sperm. Arch Androl 1990; 25(3): 243-51.

[144] Aitken RJ, Best FS, Richardson DW, et al. An analysis of sperm function in cases of unexplained infertility: conventional criteria, 
movement characteristics, and fertilizing capacity. Fertil Steril 1982; 38(2): 212-21.

[145] Wolf DP, Sokoloski JE, Quigley MM. Correlation of human in vitro fertilization with the hamster egg bioassay. Fertil Steril 1983; 40(1): 53-9.

[146] Chan SY, Fox EJ, Chan MM, et al. The relationship between the human sperm hypoosmotic swelling test, routine semen analysis, and the human sperm zona-free hamster ovum penetration assay. Fertil Steril 1985; 44(5): 668-72.

[147] Jarow JP. Diagnostic approach to the infertile male patient. Endocrinol Metab Clin North Am 2007; 36(2): 297-311.

[148] Brandes HC, van der Steen JO, de Bruin JP, et al. Unexplained infertility: overall ongoing pregnancy rate and mode of conception. Hum Reprod 2011; 26(2): 360-8.

[149] Hull MG, Glazener CM, Kelly NJ, et al. Population study of causes, treatment, and outcome of infertility. Br Med J (Clin Res Ed) $1985 ; 291(6510): 1693-7$.

[150] Collins JA. Age of the female partner is a prognostic factor in prolonged unexplained infertility: a multicenter study. Fertil Steril 1989; 52(1): 15-20.

[151] Li TS. Sperm immunology, infertility, and fertility control. Obstet Gynecol 1974; 44(4): 607-23.

[152] Hendry WF, Hughes L, Scammell G, Pryor JP, Hargreave TB. Comparison of prednisolone and placebo in subfertile men with antibodies to spermatozoa. Lancet 1990; 335(8681): 85-8.

[153] Haas GG, Manganiello P. A double-blind, placebo-controlled study of the use of methylprednisolone in infertile men with sperm-associated immunoglobulins. Fertil Steril 1987; 47(2): 295301.

[154] Ras anen M, Lahteenmaki A, Agrawal YP, Saarikoski S, Hovatta O. A placebo-controlled flow cytometric study of the effect of lowdose prednisolone treatment on sperm-bound antibody levels. Int $\mathbf{J}$ Androl 1996; 19(3): 150-4.

[155] Sharma KK, Barratt CL, Pearson MJ, Cooke ID. Oral steroid therapy for subfertile males with antisperm antibodies in the semen: prediction of the responders. Hum Reprod 1995; 10(1): 103-9.

[156] Pearce G, Tabensky DA, Delmas PD, Baker HW, Seeman E. Corticosteroid-induced bone loss in men. J Clin Endocrinol Metab 1998; 83(3): 801-6.

[157] de Almeida M, Gazagne I, Jeulin C, et al. In-vitro processing of sperm with autoantibodies and in-vitro fertilization results. Hum Reprod 1989; 4(1): 49-53.

[158] Schneider DT, Feijo CM, Verza Jr S, Esteves SC. Títulos de anticorpos antiespermatozóides antes e após o processamento seminal pela técnica do gradiente descontínuo coloidal (abstract). Int Braz J Urol 2007; 33: 795-802.

[159] Nagy VG, Liu J, Joris H, et al. Results of 55 intracytoplasmic sperm injection cycles in the treatment of male-immunological infertility. Hum Reprod 1995; 10(7): 1777-80.

[160] Lahteenmaki A, Reima I, Hovatta O. Treatment of severe male immunological infertility by intracytoplasmic sperm injection. Hum Reprod 1995; 10(11): 2824-8.

[161] Clarke GN, Bourne H, Baker HW. Intracytoplasmic sperm injection for treating infertility associated with sperm autoimmunity. Fertil Steril 1997; 68(1): 112-7.

[162] Check ML, Check JH, Katsoff D, Summers-Chase D. ICSI as an effective therapy for male factor with antisperm antibodies. Arch Androl 2000; 45(3): 125-30.

[163] Esteves SC, Schneider DT, Verza S Jr. Influence of antisperm antibodies in the semen on intracytoplasmic sperm injection outcome. Int Braz J Urol 2007; 33(6): 795-802.

[164] Huszar G, Vigue L. Correlation between the rate of lipid peroxidation and cellular maturity as measured by creatine kinase activity in human spermatozoa. J Androl 1994; 15(1): 71-7.

[165] Showell MG, Brown J, Yazdani A, Stankiewicz MT, Hart RJ. Antioxidants for male subfertility. Cochrane Database Syst Rev. (1):CD007411.
[166] Bungum M, Humaidan P, Spano M, Jepson K, Bungum L, Giwercman A. The predictive value of sperm chromatin structure assay (SCSA) parameters for the outcome of intrauterine insemination, IVF and ICSI. Hum Reprod 2004; 19(6): 1401-8.

[167] Duran EH, Morshedi M, Taylor S, Oehninger S. Sperm DNA quality predicts intrauterine insemination outcome: a prospective cohort study. Hum Reprod 2002; 17(12): 3122-8.

[168] Seli E, Gardner DK, Schoolcraft WB, Moffatt O, Sakkas D. Extent of nuclear DNA damage in ejaculated spermatozoa impacts on blastocyst development after in vitro fertilization. Fertil Steril 2004; 82(2): 378-83.

[169] Larson-Cook KL, Brannian JD, Hansen KA, Kasperson KM, Aamold ET, Evenson DP. Relationship between the outcomes of assisted reproductive techniques and sperm DNA fragmentation as measured by the sperm chromatin structure assay. Fertil Steril 2003; 80(4): 895-902.

[170] Greco SF, Iacobelli M, Rienzi L, et al. HRJ-ar. Efficient treatment of infertility due to sperm DNA damage by ICSI with testicular spermatozoa. Hum Reprod 2005; 20(1): 226-30.

[171] Said T, Agarwal A, Grunewald S, et al. Selection of nonapoptotic spermatozoa as a new tool for enhancing assisted reproduction outcomes: an in vitro model. Biol Reprod 2006; 74(3): 530-7.

[172] Said TM, Grunewald S, Paasch U, et al. Advantage of combining magnetic cell separation with sperm preparation techniques. Reprod Biomed Online 2005; 10(6): 740-6.

[173] Bartoov B, Berkovitz A, Eltes F, et al. Pregnancy rates are higher with intracytoplasmic morphologically selected sperm injection than with conventional intracytoplasmic injection. Fertil Steril 2003; 80(6): 1413-9.

[174] Kirby JD, Classen HL, Smyth JR, Froman DP. Induction of immunity to spermatozoa in male domestic fowl and effects on fertility. J Reprod Fertil 1992; 95(1): 79-86.

[175] Sakkas D, Alvarez JG. Sperm DNA fragmentation: mechanisms of origin, impact on reproductive outcome, and analysis. Fertil Steril 2010; 93(4): 1027-36.

[176] Aitken RJ, Krausz C. Oxidative stress, DNA damage and the Y chromosome. Reproduction. 2001; 122(4): 497-506.

[177] Alukal JP, Lamb DJ. Intracytoplasmic sperm injection (ICSI)-what are the risks? Urol Clin North Am 2008; 35(2): 277-88,

[178] Knoester M, Helmerhorst FM, Vandenbroucke JP, van der Westerlaken LA, Walther FJ, Veen S. Cognitive development of singletons born after intracytoplasmic sperm injection compared with in vitro fertilization and natural conception. Fertil Steril 2008; 90(2): 289-96

[179] Belva F, Henriet S, Liebaers I, Van Steirteghem A, CelestinWestreich S, Bonduelle M. Medical outcome of 8-year-old singleton ICSI children (born $>$ or $=32$ weeks' gestation) and a spontaneously conceived comparison group. Hum Reprod 2007; 22(2): 506-15.

[180] Woldringh GH, Besselink DE, Tillema AH, Hendriks JC, Kremer JA. Karyotyping, congenital anomalies and follow-up of children after intracytoplasmic sperm injection with non-ejaculated sperm: a systematic review. Hum Reprod Update; 16(1): 12-9.

[181] Liu DY, Baker HW. Evaluation and assessment of semen for IVF/ICSI. Asian J Androl 2002; 4(4): 281-5.

[182] O'Bryan MK, de Kretser D. Mouse models for genes involved in impaired spermatogenesis. Int J Androl 2006; 29(1): 76-89; discussion 105-8.

[183] Aitken RJ, Baker MA. The role of proteomics in understanding sperm cell biology. Int J Androl 2008; 31(3): 295-302.

[184] Martinez-Heredia J, de Mateo S, Vidal-Taboada JM, Ballesca JL, Oliva R. Identification of proteomic differences in asthenozoospermic sperm samples. Hum Reprod 2008; 23(4): 78391.

[185] Liu DY, Baker HW. High frequency of defective sperm-zona pellucida interaction in oligozoospermic infertile men. Hum Reprod 2004; 19(2): 228-33. 